\title{
Fire Service Instructor's undergarment choice can minimise physiological and perceptual strain
}

\author{
Emily Watkins ${ }^{*}$, Alan Richardson \\ From 15th International Conference on Environmental Ergonomics (ICEE XV) \\ Portsmouth, UK. 28 June - 3 July 2015
}

\begin{abstract}
Introduction
The South East Regional Fire Service requested an investigation into the effect of different undergarments worn by fire service instructors, to help improve thermoregulation and reduce the strain experienced. Literature suggests that wearing shorts and t-shirt may reduce heat strain [1], whilst no research has yet established the effect of wearing compression undergarments in fire environments. The study aimed to identify which type of undergarment [boiler suit (BOILER), whole body compression garments (COMPRESSION) or shorts and $t$-shirt (SHORTS)] produced the least physiological and perceptual strain.
\end{abstract}

\section{Methods}

Eight males (age $20 \pm 2$ years; weight $75.7 \pm 7.1 \mathrm{~kg}$; height $177 \pm 7 \mathrm{~cm}$ ) were monitored during three 45 mins sessions in a heat chamber $\left(49.5 \pm 1.4{ }^{\circ} \mathrm{C}\right.$ and 16.9 $\pm 4.3 \% \mathrm{rh}$ ) whilst performing intermittent exercise [5 mins walking $\left(4 \mathrm{~km} \cdot \mathrm{h}^{-1}, 1 \%\right.$ gradient $)$ and 5 mins rest]. Participants wore fire service kit and a rucksack to replicate a breathing apparatus, weighing $17 \mathrm{~kg}$ in total. Physiological and perceptual measures were recorded every $5 \mathrm{~min}$. Venous blood samples were collected before and after heat exposure for analysis of interleukin (IL)-6.

\section{Results}

Two way repeated measures ANOVA's were conducted, and revealed significant interactions for change in heart rate, change in rectal temperature $\left(\Delta \mathrm{T}_{\mathrm{re}}\right)$, volume of oxygen uptake $\left(\mathrm{VO}_{2}\right)$, physiological strain index (PSI) and IL-6, p $<0.05$. IL-6 was significantly decreased for COMPRESSION $\left(6.45 \pm 0.43\right.$ pg. $\left.\mathrm{mL}^{-1}\right)$ and SHORTS $\left(6.59 \pm 0.30\right.$ pg. $\left.\mathrm{mL}^{-1}\right)$ compared to BOILER $(6.96 \pm 0.28$

\footnotetext{
* Correspondence: E.Watkins2@uni.brighton.ac.uk

Environmental Extremes Laboratory, Centre for Sport and Exercise Science and Medicine, University of Brighton, Eastbourne, UK
}

pg.mL $\left.\mathrm{L}^{-1}\right), \mathrm{p}<0.05$. Significant differences were also present between garment types at $45 \mathrm{~min}$ for PSI and $\Delta \mathrm{T}_{\mathrm{re}}$, with trends suggesting COMPRESSION caused the lowest levels of strain $\left(4.06 \pm 0.85{ }^{\circ} \mathrm{C}\right.$, and $0.70 \pm 0.31{ }^{\circ} \mathrm{C}$, respectively) compared to SHORTS $\left(4.50 \pm 1.07{ }^{\circ} \mathrm{C}\right.$ and $0.76 \pm 0.37{ }^{\circ} \mathrm{C}$, respectively) and BOILER $\left(5.07 \pm 1.02{ }^{\circ} \mathrm{C}\right.$ and $1.00 \pm 0.56{ }^{\circ} \mathrm{C}$, respectively), $\mathrm{p}<0.05$. Thermal sensation (TSS) trends suggest that COMPRESSION (7.13 \pm $0.52)$ generated less perceptual stress in comparison to SHORTS (7.43 \pm 0.45$)$ and BOILER (7.75 \pm 0.27$), \mathrm{p}>$ 0.05 .

\section{Discussion}

Previous studies have noted no thermoregulatory improvement whilst wearing COMPRESSION in sporting situations[2,3]. However, this study suggests that in hot environments, with protective clothing, wearing COMPRESSION may be beneficial, possibly due to the thin material, tight fit, and wicking capabilities of the fabric.

\section{Conclusion}

In comparison to standard issue boiler suits or shorts and $\mathrm{t}$-shirt, wearing compression garments underneath protective clothing, during fire-fighting operations, significantly improves thermoregulation, reducing physiological strain and inflammation. Undergarment selection has a less pronounced effect on perceptions of stress; however differences may be meaningful to fire service instructors.

\section{Published: 14 September 2015}

\section{References}

1. McLellan TM, Selkirk GA: Heat stress while wearing long pants or shorts under firefighting protective clothing. Ergonomics 2004, 47(1):75-90. 
2. Roberts BC, Waller TM, Caine MP: Thermoregulatory Response to Baselayer Garments During Treadmill Exercise. International Journal of Sports Science and Engineering 2007, 1(1):29-38.

3. Goh SS, Laursen PB, Dascombe B, Nosaka K: Effect of lower body compression garments on submaximal and maximal running performance in cold $\left(10^{\circ} \mathrm{C}\right)$ and hot $\left(32^{\circ} \mathrm{C}\right)$ environments. Eur J Appl Physiol 2011, 111(5):819-26.

doi:10.1186/2046-7648-4-S1-A67

Cite this article as: Watkins and Richardson: Fire Service Instructor's

undergarment choice can minimise physiological and perceptual strain. Extreme Physiology \& Medicine 2015 4(Suppl 1):A67.

Submit your next manuscript to BioMed Central and take full advantage of:

- Convenient online submission

- Thorough peer review

- No space constraints or color figure charges

- Immediate publication on acceptance

- Inclusion in PubMed, CAS, Scopus and Google Scholar

- Research which is freely available for redistribution

Submit your manuscript at www.biomedcentral.com/submit
C Biomed Central 